B R I L L

\title{
Panascleroticoxylon crystallosa gen. et sp. nov.: a new Miocene malpighialean tree from Panama
}

\author{
Oris Rodriguez-Reyes ${ }^{1,2}$, Peter Gasson ${ }^{3}$, Carolyn Thornton ${ }^{4}$, \\ Howard J. Falcon-Lang ${ }^{5}$, and Nathan A. Jud ${ }^{6}$
}

\author{
1Smithsonian Tropical Research Institute, Box 0843-03092, Balboa, Ancón Republic of Panamá \\ ${ }^{2}$ Facultad de Ciencias Naturales, Exactas y Tecnología, Universidad de Panamá, Apartado 000 17, \\ Panamá 0824, Panamá \\ ${ }^{3}$ Jodrell Laboratory, Royal Botanic Gardens, Kew, Richmond, Surrey TW9 3DS, United Kingdom \\ ${ }^{4}$ Florissant Fossil Beds National Monument, P.O. Box 185, 15807 Teller County Road 1, \\ Florissant, CO 80816, U.S.A. \\ ${ }^{5}$ Department of Earth Sciences, Royal Holloway, University of London, Egham, \\ Surrey TW20 0EX, United Kingdom \\ ${ }^{6}$ L.H. Bailey Hortorium, Department of Plant Biology, 412 Mann Library Building, \\ Cornell University, Ithaca, NY 14853, U.S.A. \\ *Corresponding author; e-mail: orisrodriguez@gmail.com
}

\begin{abstract}
We report fossil wood specimens from two Miocene sites in Panama, Central America: Hodges Hill (Cucaracha Formation; Burdigalian, c. 19 Ma) and Lago Alajuela (Alajuela Formation; Tortonian, c.10 Ma), where material is preserved as calcic and silicic permineralizations, respectively. The fossils show an unusual combination of features: diffuse porous vessel arrangement, simple perforation plates, alternate intervessel pitting, vessel-ray parenchyma pits either with much reduced borders or similar to the intervessel pits, abundant sclerotic tyloses, rays markedly heterocellular with long uniseriate tails, and rare to absent axial parenchyma. This combination of features allows assignment of the fossils to Malpighiales, and we note similarities with four predominantly tropical families: Salicaceae, Achariaceae, and especially, Phyllanthaceae, and Euphorbiaceae. These findings improve our knowledge of Miocene neotropical diversity and highlight the importance of Malpighiales in the forests of Panama prior to the collision of the Americas.
\end{abstract}

Keywords: Miocene, Panama, fossil wood, Malpighiales, Neotropics.

[In the online version of this paper Figure 1-12 \& 13-18 are reproduced in colour.]

\section{INTRODUCTION}

Neotropical forests are among the richest in the world, and Panama (Central America) is a key area to study factors that promote high biodiversity in a small region. Paleobotanical studies contribute an important historical perspective that enhances our understanding of how the Neotropical forest structure and composition has changed through time. The recent expansion of the Panama Canal (2007-2016) provided a once-in-a-century opportunity to collect plant macrofossils from localities formerly 
obscured by overburden and dense vegetation. This work also led to renewed interest in the palaeontology of other localities outside the canal zone. Ongoing fossil studies are contributing new information concerning the systematics and biogeographic history of a variety of plant families, including Humiriaceae (Herrera et al. 2010), Malvaceae (Rodriguez-Reyes et al. 2014), Chrysobalanaceae (Jud et al. 2016), Calophyllaceae (Nelson \& Jud, in press), and Fabaceae (Rodriguez-Reyes et al., under review). In the present paper we describe a new fossil wood type from the Miocene of Panama, which further broadens our knowledge of ancient diversity of Central America.

\section{MATERIALS AND METHODS}

The specimens reported here were collected from two locations in Panama where fossil wood is abundant. The first specimen was collected from Hodges Hill on the Gaillard Cut of Panama Canal Zone, c. $25 \mathrm{~km}$ west of Panama City (latitude $09^{\circ} 02^{\prime} 51.75^{\prime \prime} \mathrm{N}$; longitude $79^{\circ} 39^{\prime} 14.02^{\prime \prime} \mathrm{W}$ ) and the second specimen was collected from the shore of Lago Alajuela (formerly Lake Madden) in Chagres National Park (latitude 09 16' $37.1^{\prime \prime}$ $\mathrm{N}$; longitude $\left.79^{\circ} 34^{\prime} 40.8^{\prime \prime} \mathrm{W}\right)$, c. $40 \mathrm{~km}$ northwest of Panama City. Both localities are Miocene in age.

\section{Geological context}

The Hodges Hill specimen was obtained from the lower Miocene Cucaracha Formation (MacFadden et al.2014), a tidally-influenced fluvial succession that has yielded a rich assemblage of fossil plants, including diverse angiosperm woods, fruits, and leaves (Berry 1918; Herrera et al.2010; Rodriguez-Reyes 2014; Rodriguez-Reyes et al. 2014; Jud et al. 2016). The specimen lies c. 30 metres below a silicic tuff with a radiometric age of ${ }^{40} \mathrm{Ar} /{ }^{39} \mathrm{Ar}$ age of $18.96 \pm 0.90 \mathrm{Ma}$ and a U-Pb zircon age of $18.81 \pm 0.30 \mathrm{Ma}$ (MacFadden et al. 2014), which places it in the Burdigalian Stage.

The Lago Alajuela specimen was obtained from the upper Miocene Alajuela Formation, a shallow marine unit (Stewart et al.1980; Jones et al. 2015), which is a prolific source of invertebrate, vertebrate, and plant fossils (Macfadden et al. 2015; Macfadden et al. 2017). The wood was collected as float in the lower part of the formation along the shore of the lake. The lower part of the Alajuela Formation consists of interbedded matrix-supported conglomerates and litharenite sandstones, and transitions to predominantly calcareous sandstones and calcarenites in the upper portion (Woodring 1957; Henderek et al. 2014). Strontium-isotope ratio analyses of scallop shells from the lower part of the formation indicate an age of $9.77 \pm 0.22 \mathrm{Ma}$, and place the fossils in the Tortonian Stage (MacFadden et al. 2017).

\section{Accession data, specimen preparation, and imaging}

Petrographic thin sections of fossil material were prepared in transverse (TS), radial longitudinal (RLS), and tangential longitudinal (TLS) sections. Sections were mounted on glass slides using EpoFix resin, ground to a thickness of $\sim 30 \mu \mathrm{m}$, and coverslips were affixed with Canada balsam. Material was observed and imaged using an Olympus binocular BH-5 with a Nikon digital camera system and software. 
The fossil woods were compared with the available images of modern and fossil woods in the InsideWood Database (IWD; insidewood.lib.ncsu.edu), Plant Resources of Tropical Africa (PROTA), key literature (Miller 1975; Mennega 1987; Hayden \& Hayden 2000), and modern wood slides in the Jodrell Laboratory of the Royal Botanic Gardens, Kew, U.K. (RBGK). Modern woods used for comparative analysis were imaged using a Leica DM LB microscope with Zeiss Axiocam HRc camera attachment and Zeiss Axiovision software.

\section{IAWA feature description and codification}

Fossil wood specimens were described using the International Association of Wood Anatomists (IAWA) List of Features for Hardwood Identification (IAWA Committee 1989). For quantitative data of vessel frequency, ray density and vessel grouping, measurements were made in 10 different fields of $1 \mathrm{~mm}^{2}$ area. For other quantitative features (mean vessel diameter, intervessel pit diameter, vessel-ray parenchyma pit diameter, vessel element length, ray height), a minimum of 30 measurements was obtained. At the start of descriptions, a list of IAWA code numbers is given modified by the following symbols: '?' indicates that there is uncertainty as to whether the feature is present and ' $\mathrm{v}$ ' indicates that the feature is variable in occurrence.

\section{SYSTEMATIC DESCRIPTION}

Order: Malpighiales

Family: incertae sedis

Genus: PanASCLERoticoxylon Rodríguez-Reyes, Gasson, Thornton, Falcon-Lang et Jud, gen. nov. (Fig. 1-18).

Type species: Panascleroticoxylon crystallosa gen. et sp.nov., Rodríguez-Reyes,

Gasson, Thornton, Falcon-Lang et Jud (Fig. 1-18).

Diagnosis: Wood diffuse porous; perforation plates simple; intervessel pits alternate; vessel-ray parenchyma pits with much reduced borders or occasionally similar to the intervessel pits; sclerotic tyloses present; paratracheal and apotracheal parenchyma extremely rare or absent; rays 1-3(-4)-seriate, strongly heterocellular, with long uniseriate tails of upright cells, occasionally $>1 \mathrm{~mm}$; crystals of varying size are present in some upright ray cells and may be solitary or of two distinct sizes per cell.

Specific diagnosis: as for the genus.

Etymology of generic name: Panascleroticoxylon is a composite of Pana, from Panama, sclerotic, indicating the abundance of sclerotic tyloses, and xylon, Greek for wood. The specific epithet crystallosa comes from the Greek, krýstallo and refers to the abundant crystals.

Holotype: STRI 36272 from Miocene (Burdigalian) of Hodges Hill, Panama, designated here, consisting of one hand specimen, and three petrographic thin sections (TS, TLS, RLS). The hand sample retrieved from the field had dimensions of $0.31 \mathrm{~m}$ (incomplete length) and $0.25 \mathrm{~m}$ (incomplete diameter).

Additional material: UF 063124 from Miocene (Tortonian) of Lago Alajuela, Panama, consisting of one hand specimen and three thin sections (TS, TLS, RLS). This small sample is water-worn, with approximate dimensions of $70 \mathrm{~mm}$ (incomplete length) and $20 \mathrm{~mm}$ (incomplete diameter). 

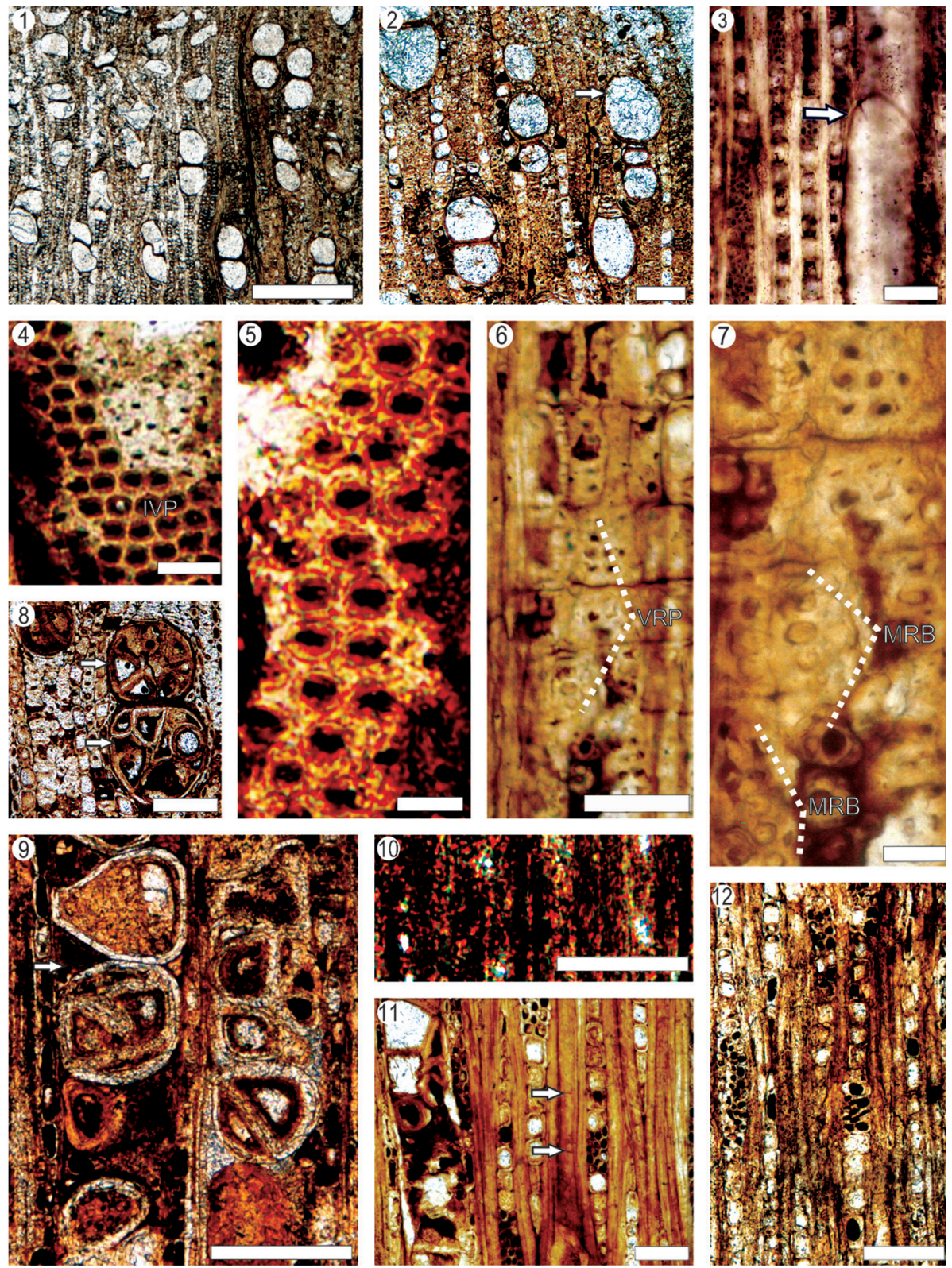

Figures 1-12. Panascleroticoxylon crystallosa Rodriguez-Reyes, Gasson, Thornton, FalconLang et Jud, sp. nov. (1, 2, 4-12: STRI 36272; 3: UF 063124). - 1: Growth rings indistinct, wood diffuse porous and absent axial parenchyma. TS. - 2: Vessels in short radial multiples of $2-3(-4)$, vessel outline oval (arrow). TS. - 3: Simple perforation plate (arrow). TLS. 4: Intervessel pitting alternate. TLS. - 5: Intervessel pitting medium to large. TLS. - 6: Vessel-ray pitting with much reduced borders to apparently simple (dotted bracket). RLS, TLS. - 7: Vessel-ray pitting showing much reduced borders to apparently simple (MRB) and occasionally 
IAWA features present: 2, 5, 13, 22, 25v, 26, 31, 42, 47v, 48, 53, 56, 57, 61, 63v, $65 \mathrm{v}, 66,69 \mathrm{v}, 70,75,78 \mathrm{v}, 97 \mathrm{v}, 98,100 \mathrm{v}, 102 \mathrm{v}, 107 \mathrm{v}, 108,110 \mathrm{v}, 115,116 \mathrm{v}, 136,137$, $140,155 \mathrm{v}$.

Descriptive note: In the following description, the mean of each specimen is reported separately, followed by the total range of values for both specimens.

Description: Growth rings indistinct; wood diffuse porous (Fig. 1); vessels solitary $(31 \%$ and $39 \%$ ) or in short radial multiples of 2-3(-4) (Fig. 1,2); solitary vessel outline oval (Fig. 1,2,13); perforation plates simple (Fig. 3); intervessel pits alternate (Fig. 4,5) and small to medium (mean pit diameter 6 and $7 \mu \mathrm{m}$; total range, up to $12 \mu \mathrm{m}$ for both specimens) (Fig. 5); vessel-ray pits with much reduced borders and occasionally similar to intervessel pitting (mean diameter $6 \mu \mathrm{m}$; total range 4-9 $\mu \mathrm{m}$ ) (Fig. 6, 7); mean tangential vessel diameters of $110 \mu \mathrm{m}$ and $112 \mu \mathrm{m}$ (total range 60-182 $\mu \mathrm{m}$ ); mean vessel density of 18.2 and 21.0 per $\mathrm{mm}^{2}$ (total range $15-27$ per $\mathrm{mm}^{2}$ ); mean vessel element length of 435 and $579 \mu \mathrm{m}$ (total range $324-850 \mu \mathrm{m}$ ); sclerotic tyloses present (Fig. 8, 9); vascular/vasicentric tracheids not observed.

Fibres with minutely bordered pits common in radial walls (Fig. 10) and occasionally in tangential walls; mostly non-septate (Fig. 11, 12) but occasionally septate (Fig. 11); thin-to-thick walls (Fig. 8, 13).

Paratracheal and apotracheal parenchyma extremely rare or absent (Fig. 1,2,13,18); axial parenchyma strands not observed.

Rays strongly heterocellular (Fig. 11, 12, 14-16), 1-3(-4)-seriate (mean 3-5) (1-5seriate in UF 063124) (Fig. 15) and occasionally > $1 \mathrm{~mm}$ (means 0.7 and 0.8 ; total range $0.22-1.6 \mathrm{~mm}$ ) (Fig. 11, 14); rays per $\mathrm{mm} 11$ and 15 (total range 9-18 per $\mathrm{mm}$ ), with long uniseriate tails (Fig. 11, 12,14) composed of procumbent cells in the body of the ray and $>4$ rows of marginal square cells (Fig. 16); sheath cells occasionally present in UF 063124 (Fig. 15).

Solitary rhomboidal crystals abundant in non-chambered (Fig. 17) and chambered square and upright ray cells (Fig. 18); crystals of varying size are present in some ray cells (Fig. 17).

Remarks: This combination of rare axial parenchyma, large alternate intervessel pits, heterocellular rays with procumbent body cells and long uniseriate tails composed of upright cells, sclerotic tyloses, and abundant crystals is unlike any other specimen known from the Miocene of Panama to date. This combination is also uncommon in the descriptions of modern and fossil wood available on the online InsideWood Database (IWD), the micromorphology reference slide collection and database in the Jodrell Laboratory of the Royal Botanic Gardens, Kew, U.K. (RBGK), and other key literature (e.g., Ilic 1991; Gasson 1996).

\footnotetext{
with distinct borders. RLS. -8 . Sclerotic tyloses present (arrows). TS. - 9: Sclerotic tyloses seen in longitudinal section (arrows). TLS. - 10: Fibres with minutely bordered pits. RLS. 11: Fibres mostly non-septate alternating with a few septate fibres (arrows) and rays with long uniseriate tails. TLS. -12 : Fibres non-septate and rays with long uniseriate tails. TLS. - Scale bars: $1=500 \mu \mathrm{m} ; 2,3,4,9,10,11=100 \mu \mathrm{m} ; 6,8=50 \mu \mathrm{m} ; 5,7=25 \mu \mathrm{m}$.
} 

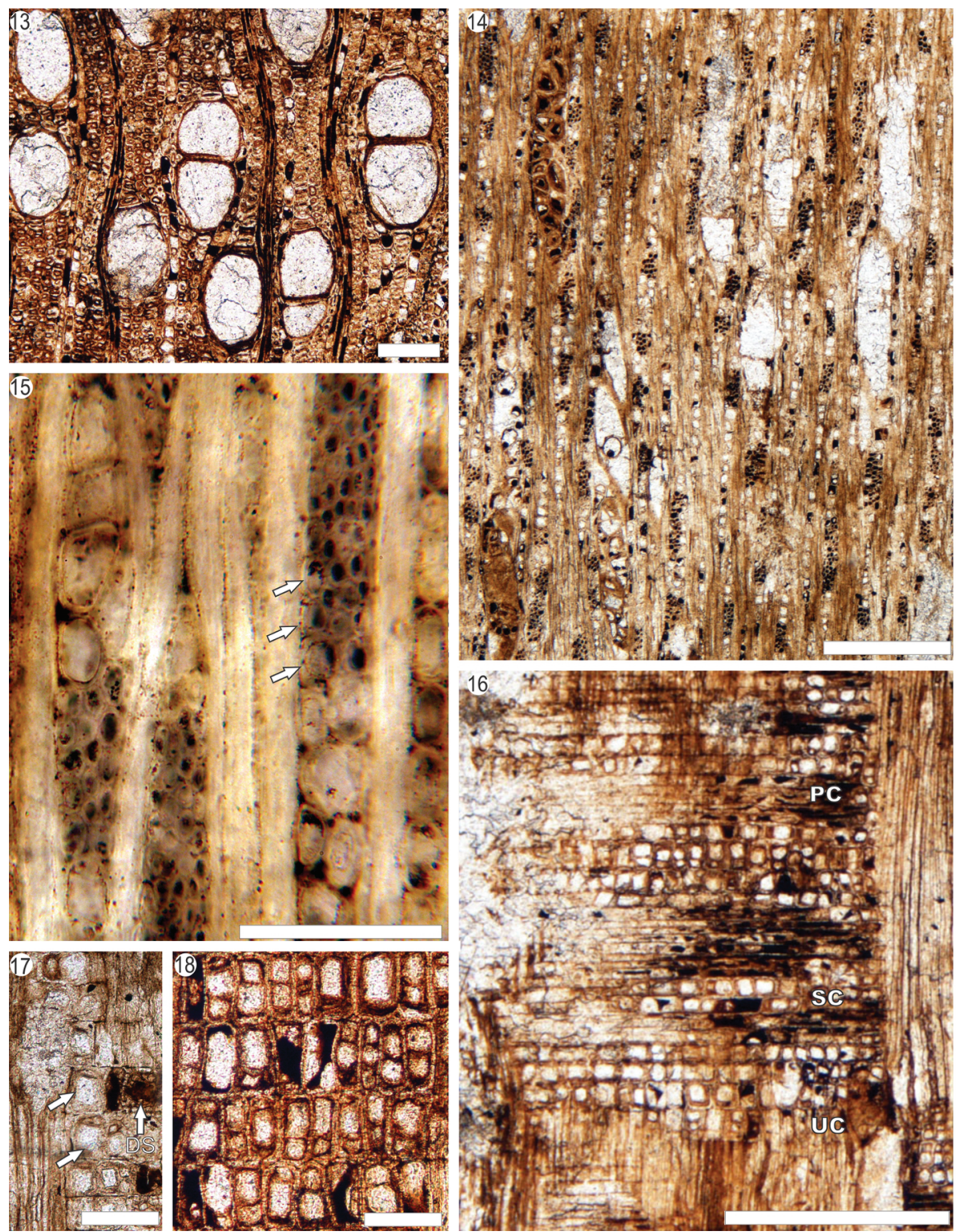

Figure 13-18. Panascleroticoxylon crystallosa Rodriguez-Reyes, Gasson, Thornton, FalconLang et Jud, sp. nov. (13, 14, 16-18: STRI 36272; 15: UF 063124). - 13: Fibres, thin- to thickwalled. TS. - 14: Rays with long uniseriate tails. TLS. - 15: Rays 1-5-seriate and one portion with uniseriate portions as wide as multiseriate portions and occasional sheath cells present (arrows). TLS. - 16: Rays composed of procumbent cells (PC) and $>4$ rows of marginal square and upright cells (SC, UC). RLS. - 17: Solitary rhomboidal crystals in ray cells (arrows) and more than one crystal per ray cell chamber (DS, arrows). RLS. - 18: Rhomboidal crystals in chambered square and upright ray cells. RLS. - Scale bars: $13=500 \mu \mathrm{m} ; 14-17=100 \mu \mathrm{m}$; $18=50 \mu \mathrm{m}$. 


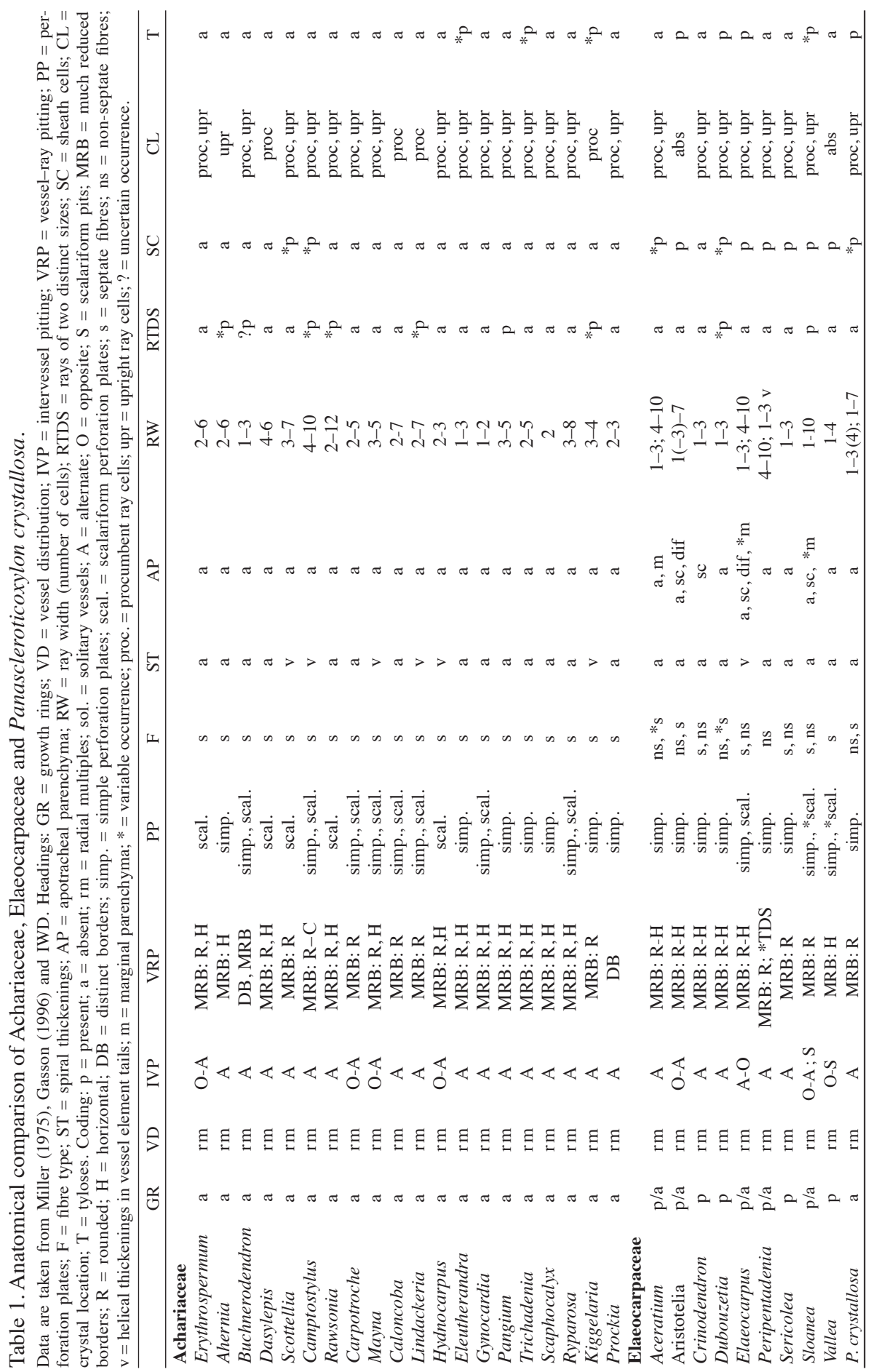




\section{PRELIMINARY SEARCHES}

We conducted searches for comparable modern material in the InsideWood Database (insidewood.lib.ncsu.edu). Our most restrictive search included wood ring porous absent (3a), wood semi-ring porous absent (4a), wood diffuse porous (5p), vessels in tangential bands absent (6a), vessels in diagonal and/or radial pattern absent (7a), vessels in dendritic pattern absent (8a), vessels exclusively solitary absent (9a), vessel clusters common absent (11a), perforation plates simple (13p), perforation plates scalariform absent (14a), intervessel pitting alternate (22p), vessel-ray pitting with much reduced borders to apparently simple (31p); axial parenchyma diffuse-in-aggregates absent (77a), axial parenchyma vasicentric absent (79a), axial parenchyma aliform absent (80a), axial parenchyma confluent absent (83a), axial parenchyma unilateral paratracheal absent (84a), axial parenchyma bands with more than three cells wide absent (85a), axial parenchyma in narrow bands up to three cells wide absent (86a), rays $1-3$-seriate $(97 p)$, rays $4-10$-seriate $(98 p)$; body ray cells procumbent with $>4$ rows of upright and/or square marginal cells (108p); oil and mucilage cells associated with ray parenchyma absent (124a); radial canals absent (130a). This search yielded 31 descriptions for modern woods in three orders: Oxalidales (Elaeocarpaceae), Malpighiales (Achariaceae, Malpighiaceae, Phyllanthaceae), and Lamiales (Acanthaceae, the monotypic shrub Trichanthera gigantea).

\section{Lamiales (Acanthaceae) excluded}

Carlquist (1988) showed that Acanthaceae typically have relatively narrow vessels with simple perforation plates, septate libriform fibres, scanty vasicentric axial parenchyma, rays both multiseriate and uniseriate, erect ray cells abundant in rays, numerous small crystals or cystoliths in ray cells in a few genera, and non-storied structure features that are similar to Panascleroticoxylon. Upon further examination, Lamiales and most Acanthaceae (including Trichanthera) we noted they have significantly more abundant vasicentric axial parenchyma than observed in the fossils. We therefore excluded Lamiales (Acanthaceae) from further consideration.

\section{Oxalidales (Elaeocarpaceae) excluded}

Two species of Elaeocarpaceae that bear some resemblance to the fossils are Elaeocarpus reticulatus (Kew 1951) (synonym E.cyaneus) from Queensland, Australia, and E. rugosus (Kew D6074) from Peninsular Malaysia and Singapore. These two species and the fossil type share the following characters: wood diffuse porous, simple perforation plates, intervessel pitting alternate and medium to large in size, vessel-ray pits with much reduced borders to apparently simple, rounded pits, tyloses common, albeit not as thick-walled as the tyloses in the fossils, fibres mostly septate but with a few non-septate ones, parenchyma absent or extremely rare, rays strongly heterocellular, 1-5-seriate with long uniseriate tails, crystals abundant in chambered ray cells and occasionally with more than one crystal of different sizes per chamber. We conducted a broader survey of the wood anatomy of Elaeocarpaceae, based on Gasson (1996) and the IWD (Table 1), and it shows that Panascleroticoxylon differs from most Elaeocarpaceae in 
the absence of opposite intervessel pitting, horizontal and in palisade vessel-ray pits, scalariform perforation plates and diverse patterns of axial parenchyma. We therefore excluded Elaeocarpaceae from further consideration.

\section{COMPARISON WITH MALPIGHIALES}

We focused subsequent comparison on the order Malpighiales. This is a diverse order of angiosperms that is important in tropical forest canopies (Davis et al.2005; Wurdack \& Davis 2009; Xi et al. 2012). Since the work of Metcalfe and Chalk (1950) that summarised dicotyledonous anatomy, the circumscription of several constituent families has changed significantly with the advent of molecular phylogenetics (Chase et al. 2002). Based on our survey of the information available in InsideWood, the families

Table 2. Anatomical comparison of selected modern woods and Panascleroticoxylon crystallosa.

Data are taken from the IWD. Headings: FAM = family; GR = growth rings $(+=$ distinct growth rings, $-=$ indistinct growth rings); $\mathrm{P}=$ porosity $(+=$ ring porous or semi-ring porous; $-=$ diffuse porous); $\mathrm{PP}=$ perforation plates; IVP = intervessel pitting size category; V-R $\mathrm{P}=$ vessel-ray pits; $\mathrm{T}=$ tyloses; $\mathrm{AP}=$ apotracheal parenchyma; $\mathrm{SF}=$ septate fibres; $\mathrm{RW}=$ maximum ray width; $\mathrm{C}=$ crystals abundant . Coding: $\mathrm{a}=$ absent, $\mathrm{p}=$ present, $\mathrm{v}=$ variable; $\mathrm{dp}=$ diffuse porous wood; $\operatorname{sim} \mathrm{p}=$ simple perforation plates, $\mathrm{scal}=$ scalariform perforation plates; $\min =$ minute; $\mathrm{s}=$ small $; \mathrm{m}=$ medium $; 1=$ large $\mathrm{MRB}=$ much reduced borders to apparently simple; DB = distinct borders and similar to intervessel pits; GL = gash like or in palisade.

\begin{tabular}{|c|c|c|c|c|c|c|c|c|c|c|c|}
\hline Taxon & FAM & GR & $\mathrm{P}$ & PP & IVP & V-R P & $\mathrm{T}$ & $\mathrm{AP}$ & SF & RW & $\mathrm{C}$ \\
\hline $\begin{array}{l}\text { Panascleroticoxylon } \\
\text { crystallosa }\end{array}$ & $?$ & $\mathrm{a}$ & $\mathrm{dp}$ & $\operatorname{simp}$ & $\mathrm{s}-\mathrm{m}$ & $\begin{array}{l}\text { MRB; } \\
\text { DB }\end{array}$ & $\mathrm{p}$ & $\mathrm{p}$ & $\mathrm{v}$ & $\begin{array}{l}1-3 \\
(4)\end{array}$ & $\mathrm{p}$ \\
\hline $\begin{array}{l}\text { Oncoba } \\
\text { brachyanthera }\end{array}$ & Salicaceae & $\mathrm{a}$ & $\mathrm{dp}$ & $\begin{array}{l}\text { scal/ } \\
\text { simp }\end{array}$ & $\mathrm{s}-\mathrm{m}$ & $\begin{array}{l}\text { MRB; } \\
\text { GL }\end{array}$ & $\mathrm{a}$ & $\mathrm{p}$ & $\mathrm{v}$ & $1-3$ & $\mathrm{p}$ \\
\hline $\begin{array}{l}\text { Casearia } \\
\text { arborea }\end{array}$ & Salicaceae & $\mathrm{a}$ & $\mathrm{dp}$ & $\operatorname{simp}$ & $\min -\mathrm{s}$ & $\mathrm{DB}$ & $\mathrm{p}$ & $\mathrm{p}$ & $\mathrm{V}$ & $4-10$ & $\mathrm{a}$ \\
\hline $\begin{array}{l}\text { Casearia } \\
\text { corymbosa }\end{array}$ & Salicaceae & $\mathrm{V}$ & $\mathrm{dp}$ & simp & $\min$ & $\mathrm{DB}$ & $\mathrm{a}$ & $\mathrm{p}$ & $\mathrm{p}$ & $1-3$ & $\mathrm{p}$ \\
\hline $\begin{array}{l}\text { Casearia } \\
\text { gossypiospermum }\end{array}$ & Salicaceae & $\mathrm{V}$ & $\mathrm{dp}$ & $\operatorname{simp}$ & $\min$ & DB & $\mathrm{a}$ & $\mathrm{p}$ & $\mathrm{v}$ & $4-10$ & $\mathrm{a}$ \\
\hline $\begin{array}{l}\text { Eleutherandra } \\
\text { pes-cervi }\end{array}$ & Achariaceae & $\mathrm{a}$ & $\mathrm{dp}$ & $\operatorname{simp}$ & $\mathrm{s}-\mathrm{m}$ & $\begin{array}{l}\text { MRB; } \\
\text { GL }\end{array}$ & $\mathrm{p}$ & $\mathrm{p}$ & $\mathrm{p}$ & $1-3$ & $\mathrm{p}$ \\
\hline $\begin{array}{l}\text { Margaritaria } \\
\text { anomala }\end{array}$ & Phyllanthaceae & $\mathrm{a}$ & $\mathrm{dp}$ & $\operatorname{simp}$ & $\mathrm{s}$ & $\begin{array}{l}\text { MRB; } \\
\text { GL }\end{array}$ & $\mathrm{p}$ & $\mathrm{p}$ & $\mathrm{V}$ & $\begin{array}{l}1-3 \\
4-10\end{array}$ & $\mathrm{p}$ \\
\hline $\begin{array}{l}\text { Margaritaria } \\
\text { discoidea }\end{array}$ & Phyllanthaceae & $\mathrm{a}$ & $\mathrm{dp}$ & simp & $\mathrm{m}$ & $\begin{array}{l}\text { MRB; } \\
\text { GL }\end{array}$ & $\mathrm{p}$ & $\mathrm{a}$ & V & $\begin{array}{l}1-3 \\
4-10\end{array}$ & $\mathrm{p}$ \\
\hline $\begin{array}{l}\text { Margaritaria } \\
\text { indica }\end{array}$ & Phyllanthaceae & $\mathrm{a}$ & $\mathrm{dp}$ & $\operatorname{simp}$ & $\mathrm{m}-1$ & MRB & $\mathrm{p}$ & $\mathrm{p}$ & $\mathrm{p}$ & $1-3$ & $\mathrm{p}$ \\
\hline $\begin{array}{l}\text { Margaritaria } \\
\text { nobilis }\end{array}$ & Phyllanthaceae & $\mathrm{a}$ & $\mathrm{dp}$ & $\operatorname{simp}$ & $\mathrm{s}-\mathrm{m}$ & $\begin{array}{l}\text { MRB; } \\
\text { GL }\end{array}$ & $\mathrm{p}$ & $\mathrm{p}$ & $\mathrm{v}$ & $\begin{array}{l}1-3 ; \\
4-10\end{array}$ & $\mathrm{p}$ \\
\hline $\begin{array}{l}\text { Phyllanthus } \\
\text { salvifolius }\end{array}$ & Phyllanthaceae & $\mathrm{a}$ & $\mathrm{dp}$ & simp & $\mathrm{m}-1$ & $\begin{array}{l}\text { MRB; } \\
\text { GL }\end{array}$ & $\mathrm{p}$ & $\mathrm{p}$ & $\mathrm{v}$ & $\begin{array}{l}1-3 ; \\
4-10\end{array}$ & $\mathrm{a}$ \\
\hline Acalypha & Euphorbiaceae & $\mathrm{a}$ & $\mathrm{dp}$ & $\begin{array}{l}\text { scal/ } \\
\text { simp }\end{array}$ & $?$ & $\begin{array}{l}\text { MRB; } \\
\text { GL }\end{array}$ & $\mathrm{a}$ & $\mathrm{p}$ & $\mathrm{p}$ & $4-10$ & $\mathrm{a}$ \\
\hline
\end{tabular}


with genera most like Panascleroticoxylon are in the Achariaceae, Euphorbiaceae, Phyllanthaceae and Salicaceae; however, it is difficult to assign the new taxon to any one of those families because of the substantial overlap in wood anatomical features. Unfortunately, there are many species of Euphorbiaceae that are not represented in the collections we examined nor reported in the literature, which limits the total coverage of the family for this comparison.

In the IWD search result reported above, genera of Malpighiales represented by only one species include Mahurea sp. (Calophyllaceae), Rinorea pugionifera (Violaceae), and Glandonia macrocarpa (Malpighiaceae). The first two differ from the fossil type because they have reticulate perforation plates, diffuse axial parenchyma and the occasional rays of two distinct sizes, whereas the latter differs in its exclusively septate fibres and small vessels in long radial multiples. About half of the results of the IWD search were species that belong to four families of the Malpighiales: Achariaceae, Euphorbiaceae, Phyllanthaceae, and Salicaceae. We therefore conducted a detailed study of these families. In Table 2, we provide a comparative summary of Panascleroticoxylon crystallosa and selected modern woods including Phyllanthaceae, Salicaceae and Euphorbiaceae.

\section{Comparison with Salicaceae}

Salicaceae Mirbel comprises 54 genera and 1200 species (Stevens 2001-onwards). Diffuse porous wood, intervessel pitting alternate, axial parenchyma rare to absent, tyloses common and abundant crystals are traits present in most of the tropical Salicaceae and are traits shared with P. crystallosa. From the surveyed Salicaceae, several features not present in Panascleroticoxylon include scalariform perforation plates (e.g., Idesia polycarpa, Hasseltia sp., Oncoba brachyanthera); helical thickenings in Azara, Bennettiodendron leprosipes, Carrierea calycina, Macrohasseltia macroterantha; very small vessels (e.g., Calantica cerasifolia, Trimeria tropica); druses abundant (e.g., Carrierea calycina, Casearia battiscombei); vessel-ray pits unilaterally compound (e.g., Itoa stapfi); axial parenchyma present (e.g., Oncoba spinosa); ray density $>12 / \mathrm{mm}$ in Trimeria tropica; rays mostly biseriate (e.g., Xylosma japonicum, X. sumatrana). Species of Casearia, a genus widely distributed in South America, has intervessel pitting minute (although not in all species) and exclusively septate fibres; whereas intervessel pits small to medium and abundant non-septate fibres combined with a few septate fibres occur in Panasclaroticoxylon crystallosa. There are scalariform perforation plates in Dovyalis, Olmediella, Azara, Benettiodendron, Hasseltiopsis, Hecatostemon, Ludia, Tisonia, Lunania, Neoptychocarpus, Scolopia, Tetrathylacium, Zuelania and Homalium. Laetia possesses minute intervessel pitting. Septate fibres are abundant in species of Ahernia. Salix and Populus can be distinguished because of the numerous narrow vessels, very commonly with angular outline and exclusively uniseriate rays. Almost all Banara species have helical thickenings. Species of Bembicia, Flacourtia, Ophyobotris possess vessel-ray pitting similar to intervessel pitting in shape and size. Bivinia and Scolopia have long radial multiples and numerous narrow vessels. Based on our review of Salicaceae, we conclude that among Malpighiales, it is probably the least likely match for P. crystallosa. 


\section{Comparison with Achariaceae}

Achariaceae Harms is a pantropical family with 30 genera and 145 species. Further study of the Achariaceae was conducted using IWD, samples in the collection of the RBGK and key literature (Miller 1975) (Table 1). This review revealed key traits that are very common for the family and that are not observed in the fossils, such as the occurrence of scalariform perforation plates (e.g., Buchnerodendron, Carpotroche, Dasylepis, Erythrospermum, Gynocardia, Hydnocarpus, Lindackeria, Rawsonia and Scottellia). Exclusively septate fibres occur in Erythrospermum, Lindackeria, Rawsonia, Ryparosa, Trichadenia. Other characters that differ from the fossil are the absence of crystalliferous chains (e.g., Gynocardia, Hydnocarpus, Mayna, Rawsonia, Scaphocalyx) and the occurrence of opposite intervessel pitting as reported in Miller's (1975) work for species of Carpotroche. Among all of the surveyed Achariaceae, the taxon that best matches the anatomy of Panascleroticoxylon crystallosa is Eleutherandra, a monotypic genus from South-East Asia. It differs from the fossils in having exclusively septate fibres, and there are no crystals in parenchyma cells. Therefore, Eleutherandra is, also, considered an unlikely match. While we note that some Achariaceae combine many features that also occur in the fossils, members of the family typically have scalariform perforation plates making it an unlikely match for the fossils.

\section{Affinities with Phyllanthaceae}

Phyllanthaceae Martynov is a family of 59 genera and includes most of the former Phyllanthoideae (Euphorbiaceae) except for Drypetes and relatives (Stevens 2001onward). Phyllanthaceae is a very diverse family in terms of wood anatomical features as we discovered through a review of the IWD, literature such as Mennega (1987), PROTA and studies of slides in the RBGK collection. Based on the work of Mennega (1987), where 12 tribes of Phyllanthoideae (under the old Euphorbiaceae) are described and photographed, it appears that diffuse apotracheal parenchyma is present in most of the taxa (although the author recognised a few exceptions) and scalariform and simple perforation plates commonly co-occur in individual specimens.

For the IWD-listed Phyllanthaceae, several species can be ruled out as potential matches because they have distinct growth rings and gums, rather than tyloses, in heartwood vessels (e.g., Bischofia javanica, Glochidion acuminatum); minute intervessel pitting (Glochidion lanceolatum); crystals in enlarged ray cells (Glochidion lanceolatum, G. marchionicum, G. zeylanicum); exclusively septate fibres (e.g., Glochidion philippicum, G. rubrum, Hymenocardia acida, Phyllanthus emblica); fibres with distinctly bordered pits (Hymenocardia ulmoides, Phyllanthus polyanthus); rays commonly $>10$ cells wide (e.g., Phyllanthus pervilleanus). Antidesma madagascariense and A. pulvinatum, both with rays of two distinct sizes.

Margaritaria is the listed Phyllanthaceae that most resembles Panascleroticoxylon, with a few differences, e.g., vessels are very narrow and numerous $\left(40-100 \mathrm{~mm}^{-1}\right)$ in M. anomala, same as M. indica (Prakash-Jangid \& Gupta 2016); diffuse axial parenchyma is present in $M$. discoidea and M.nobilis lacks the highly heterocellular rays and the abundant crystals of $P$. crystallosa. In general, diffuse axial parenchyma occurs in several species of Margaritaria, and it is not observed in the fossils. Furthermore, the 
combination of vessel-ray pits with much reduced borders with a few ones similar to the intervsessel pitting that occurs in the fossils, was not observed in Margaritaria.

\section{Comparison with Euphorbiaceae}

To survey the wood anatomy of the 6745 species of Euphorbiaceae is beyond the scope of this publication. Some features that are very common in the family are: combination of vessels solitary and in radial multiples, simple perforation plates, large alternate intervessel pitting, septate fibres, rays markedly heterocellular, absence of parenchyma and crystals in chambered ray parenchyma (Wheeler \& Manchester 2002).

We note some of the important and common characters for the family among the taxa we reviewed, based on IWD searches, PROTA and observations in the RBGK slide collection as follows: axial parenchyma is abundant and commonly diffuse-inaggregates (e.g., Adelia, Alchornea, Aleurites, Brasiliocroton, Cleidion, Macaranga, Trewia); axial parenchyma reticulate (e.g., Glycydendron, Hevea); axial parenchyma in narrow bands up to 3 cells wide (e.g., Balakata, Colliguaja, Discoglypremna, Dodecastigma, Hancea, Homonoia, Klaineanthus, Omphalea, Pausandra, Plagiostyles, Wetria). Another common characteristic in Euphorbiaceae woods is exclusively uniseriate rays (e.g., Adelia, Alchornea, Aparisthium, Cyrtogonone, Dodecastigma, Hancea, Mallotus, Plagiostyles, Sapium). Following examination of the available Euphorbiaceae slides in the RBGK collection and images in the IWD, we did not find any genus with a combination of characters that matches the fossil, Panascleroticoxylon crystallosa.

Acalyphoideae is the largest and most complex of the five subfamilies of the Euphorbiaceae. Its diversity can be summarised via statistics from Webster's (1994) classification: 20 tribes, 116 genera, and c. 2,000 species that are found throughout the world, but are especially abundant in the tropics; approximately $86 \%$ of acalyphoid genera can be characterised as woody. Hayden and Hayden (2000) reviewed the Alcalyphoideae. Their survey indicates that similarity to the Panamanian fossil wood in features such as absence of growth rings, vessels solitary and in short radial multiples, perforation plates exclusively simple in most of the genera (except for Microdesmis and Panda), intervessel pitting alternate, vessel-ray pits circular to elongate, fibres mostly non-septate, sclerotic tyloses, heterocellular rays, and crystals. However, there are features that distinguish some genera, e.g., simple and scalariform perforation plates combined in Acalypha, Adenophaedra, Agrostistachys, Aparisthmium, Bernardia tamanduana, Botryophora, Caryodendron grandifolium, Claoxylon, Cleidion, Cnesmone, Coccoceras, Conceveiba krukoffii, C. guianensis, Dicoelia, Discoclaoxylon, Galearia, Macaranga zenkeri, some species of Mallotus, Mareya, Mercurialis (Williams 1936; Metcalfe \& Chalk 1950; Normand 1955), Pogonophora (Metcalfe \& Chalk 1950), and Tragia (Metcalfe \& Chalk 1950). The most obvious difference between the subfamily and the Panamanian fossil wood is the occurrence of diffuse axial parenchyma.

Mennega (1987) provided the most complete survey for the Euphorbiaceae wood anatomy available to date. Putranjavaceae (former Drypeteae) and Pandaceae (former Dicoelieae), have minute intervessel pitting and vessel-ray pitting similar to the intervessel pits, different from the fossils. As the author details, a circumscription of the anatomy of euphorbiaceous woods is difficult; however, a few generalised patterns are 
Table 3. Anatomical comparison of fossil woods assigned to Euphorbiaceae, Phyllanthaceae and Panascleroticoxylon crystallosa.

Data are taken from the IWD. Headings: $\mathrm{GR}=$ growth rings; $\mathrm{P}=$ porosity; $\mathrm{PP}=$ perforation plates; IVP = intervessel pitting size category; $\mathrm{V}-\mathrm{R} \mathrm{P}=$ vessel-ray pits; $\mathrm{T}=$ tyloses; $\mathrm{AP}=$ apotracheal parenchyma; $\mathrm{SF}=$ septate fibres; $\mathrm{RW}$ = maximum ray width $\mathrm{C}=$ crystals abundant $+1 \mathrm{CRY}=$ crystals of different sizes in a single ray cell. Coding: $\mathrm{K}=\mathrm{Cretaceous}, \mathrm{E}=$ Eocene, $\mathrm{M}=$ Miocene, $\mathrm{C}=$ Cenozoic, $\mathrm{N}=$ Neogene, $\mathrm{O}=$ Oligocene; $\mathrm{p}=$ present, $\mathrm{a}=$ absent, $\mathrm{v}=$ variable; $\mathrm{MRB}=$ vessel-ray pits with much reduced borders to apparently simple; $\mathrm{DB}=$ vessel-ray pits with distinct borders and similar to intervessel pits, $\mathrm{GL}=$ vessel-ray pits gash-like (or in palisade); $\mathrm{d}-\mathrm{i}-\mathrm{a}=$ apotracheal parenchyma diffuse-in-aggregates; $\mathrm{r}=$ parenchyma rare or absent; $\mathrm{sc}$ = parenchyma scanty paratracheal; $\mathrm{u}$ = parenchyma unilateral; vas = apotracheal parenchyma vasicentric.

\begin{tabular}{|c|c|c|c|c|c|c|c|c|c|c|c|c|}
\hline Taxon & Age & GR & $\mathrm{P}$ & PP & IVP & V-R P & $\mathrm{T}$ & AP & $\mathrm{SF}$ & RW & $\mathrm{C}$ & $\begin{array}{c}+1 \\
\text { CRY }\end{array}$ \\
\hline $\begin{array}{l}\text { Panasclericoxylon } \\
\text { crystallosa }\end{array}$ & & $\mathrm{a}$ & $\mathrm{a}$ & & $\mathrm{s}-\mathrm{m}$ & $\begin{array}{l}\text { MRB; } \\
\text { DB }\end{array}$ & $\mathrm{p}$ & $\mathrm{r}$ & $\mathrm{v}$ & $\begin{array}{l}1-3 \\
(4)\end{array}$ & $\mathrm{p}$ & $\mathrm{p}$ \\
\hline $\begin{array}{l}\text { Securinegeoxylon } \\
\text { biseriatum }\end{array}$ & K & $\mathrm{a}$ & $\mathrm{a}$ & $+/-$ & $?$ & MRB & $\mathrm{p}$ & $r$ & $\mathrm{p}$ & $1-3$ & $\mathrm{a}$ & $\mathrm{a}$ \\
\hline $\begin{array}{l}\text { Securinegeoxylon } \\
\text { bacense }\end{array}$ & K & $\mathrm{a}$ & $\mathrm{a}$ & $+/-$ & $?$ & MRB & $\mathrm{p}$ & d-i-a & $\mathrm{p}$ & $1-3$ & $\mathrm{p}$ & $\mathrm{a}$ \\
\hline $\begin{array}{l}\text { Heveoxylon } \\
\text { microporosum }\end{array}$ & $\mathrm{E}$ & $\mathrm{a}$ & $\mathrm{a}$ & $\mathrm{a}$ & $\min$ & MRB & $\mathrm{p}$ & $\mathrm{r} ; \mathrm{sc}$ & $\mathrm{p}$ & $1-3$ & $\mathrm{a}$ & $\mathrm{a}$ \\
\hline $\begin{array}{l}\text { Piranheoxylon } \\
\text { stockmansi }\end{array}$ & $\mathrm{E}$ & $\mathrm{a}$ & $\mathrm{a}$ & $\mathrm{a}$ & $\min$ & DB & $\mathrm{a}$ & $\mathrm{d}-\mathrm{i}-\mathrm{a} ; \mathrm{b}$ & $\mathrm{p}$ & $1-3$ & $\mathrm{a}$ & $\mathrm{a}$ \\
\hline $\begin{array}{l}\text { Aleurites } \\
\text { miocenica }\end{array}$ & M & $\mathrm{a}$ & $\mathrm{p}$ & $\mathrm{a}$ & 1 & MRB & $\mathrm{a}$ & d-i-a & $\mathrm{p}$ & 1 & $\mathrm{a}$ & a \\
\hline $\begin{array}{l}\text { Bischofia } \\
\text { palaeojavanica }\end{array}$ & M & $\mathrm{a}$ & $\mathrm{a}$ & $\mathrm{a}$ & 1 & $\begin{array}{l}\mathrm{DB} \\
\mathrm{MRB}\end{array}$ & $\mathrm{p}$ & $\mathrm{r} ; \mathrm{sc}$ & $\mathrm{p}$ & $4-10$ & $\mathrm{a}$ & a \\
\hline $\begin{array}{l}\text { Bischofia } \\
\text { javanoxyla }\end{array}$ & M & $\mathrm{a}$ & $\mathrm{a}$ & $\mathrm{a}$ & 1 & MRB & $\mathrm{a}$ & $\mathrm{r} ; \mathrm{sc}$ & $\mathrm{p}$ & $4-10$ & $\mathrm{p}$ & a \\
\hline $\begin{array}{l}\text { Bischofia } \\
\quad \text { maomingensis }\end{array}$ & $\mathrm{E}$ & $\mathrm{a}$ & $\mathrm{a}$ & $\mathrm{a}$ & 1 & MRB & $\mathrm{p}$ & $\mathrm{r} ; \mathrm{u}$ & $\mathrm{p}$ & $4-10$ & $\mathrm{p}$ & a \\
\hline $\begin{array}{c}\text { Bischofioxylon } \\
\text { miocenicum }\end{array}$ & M & $\mathrm{p}$ & $\mathrm{a}$ & $\mathrm{a}$ & 1 & MRB & $\mathrm{p}$ & sc; vas & $\mathrm{p}$ & $\begin{array}{l}1-3 \\
4-10\end{array}$ & $\mathrm{p}$ & a \\
\hline $\begin{array}{l}\text { Bischofinium } \\
\text { deccani }\end{array}$ & K & $\mathrm{a}$ & $\mathrm{a}$ & $\mathrm{a}$ & $?$ & MRB & $\mathrm{p}$ & sc; vas & $\mathrm{p}$ & $4-10$ & $\mathrm{a}$ & a \\
\hline $\begin{array}{l}\text { Phyllanthus } \\
\text { wuhanensis }\end{array}$ & $\mathrm{C}$ & $\mathrm{a}$ & $\mathrm{a}$ & $\mathrm{a}$ & $?$ & GL & $\mathrm{a}$ & $r$ & $\mathrm{p}$ & $2-6$ & a & $\mathrm{a}$ \\
\hline$\frac{\underline{\text { Bridelia }}}{\text { wuhanensis }}$ & $\mathrm{C}$ & $\mathrm{a}$ & $\mathrm{a}$ & $\mathrm{a}$ & $?$ & GL & $\mathrm{p}$ & $r$ & $\mathrm{p}$ & $\begin{array}{l}3-4 \\
(5)\end{array}$ & $\mathrm{p}$ & $\mathrm{a}$ \\
\hline $\begin{array}{l}\text { Bridelioxylon } \\
\text { arnouldii }\end{array}$ & $\mathrm{O}$ & $\mathrm{a}$ & $\mathrm{a}$ & $\mathrm{a}$ & $?$ & $?$ & $\mathrm{a}$ & $\mathrm{sc}$ & $\mathrm{p}$ & $1-3$ & a & a \\
\hline $\begin{array}{l}\text { Bridelioxylon } \\
\text { cuddalorense }\end{array}$ & $\mathrm{N}$ & $\mathrm{a}$ & $\mathrm{a}$ & $\mathrm{a}$ & $?$ & $\begin{array}{l}\text { MRB; } \\
\text { DB }\end{array}$ & $\mathrm{a}$ & sc; vas & $\mathrm{p}$ & $1-3$ & $\mathrm{a}$ & a \\
\hline $\begin{array}{l}\text { Bridelioxylon } \\
\text { fibrosum }\end{array}$ & $\mathrm{K}$ & $\mathrm{a}$ & $\mathrm{a}$ & $\mathrm{a}$ & $?$ & MRB & $\mathrm{p}$ & $\mathrm{r} ; \mathrm{sc}$ & $\mathrm{p}$ & $1-3$ & $\mathrm{a}$ & a \\
\hline $\begin{array}{l}\text { Bridelioxylon } \\
\text { keriense }\end{array}$ & M & $\mathrm{a}$ & $\mathrm{a}$ & $\mathrm{a}$ & 1 & MRB & $\mathrm{p}$ & d-i-a; sc & $?$ & $1-3$ & $\mathrm{a}$ & a \\
\hline $\begin{array}{c}\text { Mallotoxylon } \\
\text { assamicum }\end{array}$ & M & $\mathrm{a}$ & $\mathrm{a}$ & a & 1 & $?$ & $\mathrm{p}$ & d-i-a & $\mathrm{a}$ & $1-3$ & a & a \\
\hline
\end{tabular}


as follows: simple perforation plates, medium to large intervessel pitting, apotracheal parenchyma, and numerous narrow heterocellular rays. From that premise, we could say that many Euphorbiaceae possess axial parenchyma, which is absent in Panascleroticoxylon crystallosa. Nonetheless, we cannot totally rule out the family, because there is a limited representation of Euphorbiaceae in reference collections. We only point out that from all the species reviewed, we have not found any reasonable match with P. crystallosa.

\section{COMPARISON WITH FOSSIL WOODS}

Many of the fossil taxa assigned to families of the order Malpighiales have not been critically re-evaluated in the light of its modern phylogeny, so it represents an issue when studying the fossil record. However, evaluating the accuracy of the identifications of fossils assigned to the Malpighiales is beyond the scope of this publication. We focus our discussion on fossil woods considered related to Euphorbiaceae and Phyllanthaceae, because those are the two families that appear to be a better match to the fossils described in this paper, and we show that Panascleroticoxylon differs from all of these in combining absent parenchyma, vessel-ray pits with much reduced borders to apparently simple and rays heterocellular with long uniseriate tails. (Table 3).

\section{Cretaceous records}

Cretaceous woods whose names suggest malpighialean affinities are: Bridelioxylon bohemicum, Securinegeoxylon biseriatum, and S. bacense. Bridelioxylon bohemicum was described based on fossils from the Cretaceous of Bohemia (Prakash \& Brezinova 1970); it has abundant diffuse axial parenchyma. Securinegeoxylon biseriatum and $S$. bacense were described from Maastrichtian localities in South Africa and they both have scalariform perforation plates and scanty paratracheal parenchyma (Mädel 1962). All of these are readily distinguished from Panascleroticoxylon crystallosa. Bridelioxylon krauselii, retrieved from the Deccan Intertrappean Beds, has vessels in very long radial multiples and distinct growth rings, different from P. crystallosa.

\section{Eocene records}

A few woods from Eocene localities are assigned to Euphorbiaceae and Phyllanthaceae (Table 3), but none of these match Panascleroticoxylon. Heveoxylon microporosum from Eden Valley, Wyoming (Kruse 1954) has axial scanty paratracheal parenchyma, but lacks crystals, and has ray-vessel pitting unlike Panascleroticoxylon . Paraphyllanthoxylon lignitum from different Eocene deposits of Europe has rays of two distinct sizes, a trait that is absent in Panascleroticoxylon crystallosa. Numerous permineralised specimens related to Malpighiales are known from the Nut Beds flora (Wheeler \& Manchester 2002). Several of those have not been assigned to any family, e.g. Clarno Malpighialean Wood Type 1 (?Euphorbiaceae) and Hydnocarpoxylon, both possess scalariform perforation plates, not observed in P. crystallosa. Also, crystals were not observed in the Clarno Nut Beds woods (Wheeler \& Manchester 2002), a feature that is very abundant in the Panamanian fossil wood type. Piranheoxylon stockmansi 
(Grambast 1961), retrieved from the Eocene of Belgium, has diffuse axial parenchyma, marginal bands of parenchyma and vessel-ray pitting similar to the intervessel pitting.

\section{Oligocene and Miocene records}

One of the few reported Malpighiales Oligocene woods is Bridelioxylon arnouldi (Koeniguer 1966). It has scanty paratracheal parenchyma and opposite intervessel pits, two traits absent in Panascleroticoxylon crystallosa. Reports of Malpighian fossil woods are abundant in the Miocene (see Table 3). Aleurites miocenica from Japan (Watari 1956) has abundant parenchyma. Bischofia palaeojavanica from the Dhemaji and Lakhimpur districts of Assam, considered to be of middle-upper Miocene, possesses scanty paratracheal parenchyma and fibres exclusively septate (Mehrotra et al. 2011). Bischofia javanica has scanty paratracheal parenchyma (Cheng et al. 2005). Bischofia javanoxyla has rays 1-6 cells wide (Li et al. 2003), possess wide vessels in radial multiples of 4-10, whereas P. crystallosa tends to have multiples of only up to 4 in the Alajuela specimen. Another species, Bischofioxylon miocenicum from South India, is also easily distinguished from P. crystallosa because it has vasicentric parenchyma (Ramanujan 1960). Qi et al. (1997) published three euphorbian woods from Wuhan: Phyllanthus wuhanensis has vessel-ray pits gash-like, tyloses sclerotic common, septate fibres dominant; Bridelia whanensis, with long radial multiples (up to 6), axial parenchyma apotracheal diffuse, sclerotic tyloses, and Bischofia polycarpa with vasicentric parenchyma. Species of Bridelioxylon are also distinct from the Panamanian fossil. Bridelioxylon keriense does not show rays with long uniseriate tails. Bridelioxylon cuddalorense (South Arcot district, India) has vasicentric parenchyma.

\section{MALPIGHIALES IN NEOTROPICAL FORESTS}

Malpighiales is strongly supported as a monophyletic group, based on broad and comprehensive studies of the extant diversity (e.g., Davis et al. 2005; Wurdack \& Davis 2009; Xi et al. 2012); however, some relationships within the order remain problematic. The complicated determination of deep relationships within Malpighiales seems to be related to the rapid origin and diversification of the group in mid-Cretaceous times (Davis et al. 2005; Wurdack \& Davis 2009). Our knowledge of relationships within Malpighiales has been in flux in recent years. This is especially the case for the former Flacourtiaceae, whose members were re-distributed into Salicaceae, Achariaceae and Samydaceae, following extensive analysis using $r b c L D N A$ sequences (Chase et al. 2002), and the Euphorbiaceae, which remained largely unresolved until the 4-gene analysis of Davis et al. (2005).

\section{Fossil record in Panama}

Fossil Malpighiales have been reported from the Panama Canal and other basins in Panama. Most of the permineralised plant fossils described from the Lirio East plant locality so far belong to the Malpighiales, including fruits of Humiriaceae (Herrera et al.2010). Humiriaceous wood was also reported from the Eocene-Miocene deposits of the Azuero Peninsula (Stern \& Eyde 1963; Herrera et al. 2014). Jud et al. (2016) 
reported Chrysobalanaceae retrieved from lower Miocene deposits along the Panama Canal. The identifications were based on fossil permineralised endocarps of Parinari panamensis and a fossil wood, Parinarioxylon panamense, both representing the oldest evidence of Chrysobalanaceae. Calophyllaceae is represented in the flora as well by a fossil Mammea (Calophyllaceae) identified from wood and bark anatomy (Nelson \& Jud, in press).

Euphorbiaceae (Alchornea, Sapium) have been identified from pollen grains from the lower Miocene Culebra Formation and the Pliocene Gatun Formation (Graham 1988, 1991). Recently, 'euphorboid' fossil woods were reported from the late Miocene Alajuela Formation (McFadden et al. 2015). Also, endocarps from the Cucaracha Formation have been assigned to Euphorbiaceae (Herrera et al. 2014).

\section{Biogeographic implications}

Today Malpighiales have c. 16,000 species (c.6\% of all angiosperms), comprising many well-known tropical families and they are an important component of the understory in tropical rainforests worldwide (Davis et al. 2005). Early members of this order probably occupied closed-canopy tropical forests and rainforests during the mid-Cretaceous and dominated in the wettest environments by Late Cretaceous (Whitmore 1998; Davis et al. 2005). Therefore, Malpighiales are a key element in the origin of rainforests and persist today as one of their most important components. This study, together with other plant remains from the Panama Canal, support a rich fossil record of Malpighiales for the Miocene of Panama and Central America and adds to the evidence of a rich diversity of Malpighiales in the Neotropics during the Miocene.

\section{ACKNOWLEDGEMENTS}

ORR acknowledges funding from the Secretaría Nacional de Ciencia, Tecnología e Innovación (SENACyT), Panama, the PIRE project, and a Crossland Scholarship held at Royal Holloway, University of London. HFL acknowledges a NERC Advanced Fellowship held at Royal Holloway, University of London. NAJ acknowledges funding from the PCP-PIRE, Project 0966884. The authors are thankful to Dr. Carlos Jaramillo for his helpful comments and to M-I Barreto for her help with fieldwork logistics. Special thanks go to Carlos De Gracia and Liliana Londoño for their great help during fieldwork, Neil Holloway for making thin sections and Kevin D'Souza and Francy Carvajal for their help with imaging. We are very thankful to the two anonymous reviewers and the editor, for greatly improving this work with their comments.

\section{REFERENCES}

Bentham G, Hooker JD. 1862. Genera plantarium: ad exemplaria imprimis in Herberiis Kewensibus servata dfinita. Volume 1, Part 1.

Berry EW. 1918. The fossil higher plants from the Canal Zone. Bull. US Nat. Mus. 103: $15-44$.

Carlquist S. 1988. Comparative wood anatomy: systematic, ecological and evolutionary aspects of dicotyledon wood. Springer.

Chase M, Smarzty S, Lledó MD, Wurdack S, Swensen M, Fay M. 2002. When in doubt, put in Flacourtiaceae: a molecular phylogenetic analysis based on Plastid rbcL DNA sequences. Kew Bull. 57: 141-181. 
Cheng YM, Wang YF, Li CS, Jiang C. 2005. Fossil woods of Bischofia javanica Bl. from the Pliocene and palaeoenvironmental implication in Yuanmou Basin, Yunnan Province. J. Palaeogeography (Chinese edition) 7: 107-112.

Davis CC, Webb CO, Wurdack J, Jaramillo C. 2005. Explosive radiation of Malpighiales supports a Mid-Cretaceous origin of modern tropical rain forests. Amer. Nat. 165: E36-E65.

Gasson P. 1996. Wood anatomy of Elaeocarpaceae. In: Donaldson LA, Singh AP, Butterfield BG, Whitehouse LJ (eds.), Recent advances in wood anatomy: 47-71. NZFI Ltd, Rotorua.

Graham A. 1988. Studies in Neotropical Paleobotany. VI. The lower Miocene communities of Panama - -Tthe Cucaracha Formation. Ann. Missourio. Bot. Gard. 75 (4): 1467-1479.

Graham A. 1991. Studies in Neotropical Paleobotany. VIII. The Pliocene communities of Panama - Introduction and ferns, gymnosperms, angiosperms (Monocots). Ann. Missouri Bot. Gard. 78: 190-200.

Grambast N. 1961. Piranheoxylon stockmansi n.gen., n.sp. Bois d'Euphorbiacées de l'EÉocène de Belgique . Bull. Inst. Roy. Sci. Natur. Belg. 37: 1-12.

Hayden J, Hayden S. 1999. Wood anatomy of Acalyphoideae (Euphorbiaceae). IAWA J. 21: 213-235.

Henderek RL, Moreno-Bernal JW, Von Dassow W, Wood AR, Hendy AJ, Whiting E, Barboza MM, MacFadden BJ. 2014. Geological reconnaissance of the middle-late Miocene Alajuela Formation (Panama): Implications for shoaling of the Central American Seaway. October 2014 GSA Annual Meeting Vancouver, British Columbia.

Herrera F, Manchester S, Jaramillo C, MacFadden B, Da Silva-Caminha S. 2010. Phytogeographic history and phylogeny of Humiriaceae. Int. J. Plant Sci. 171: 392-408.

Herrera F, Manchester S, Vélez-Juarbe J, Jaramillo C. 2014. Phytogeographic history of the Humiriaceae. Part 2. Int. J. Plant Sci. 175:doi: 10.1086/676818.

IAWA Committee. 1989. IAWA List of microscopic features for hardwood identification. IAWA Bull. n.s. 10: 219-332.

Ilic J. 1991. CSIRO Atlas of Hardwoods. Springer. 525 pp.

Jones D, Wood AR, MacFadden BJ. 2015. Fossil invertebrates and Sr-isotope age estimate for the Alajuela Formation, central Panama. 4th Meeting of the NNB4 Program and Abstracts.

Jud NA, Nelson CW, Herrera F. 2016. Fruits and wood of Parinari from the early Miocene of Panama and the fossil record of Chrysobalanaceae. Amer. J. Bot. 103: 277-289.

Koeniguer JC. 1966. Étude paléoxylologique de la Libye. I. Sur un bois fossile de l'Oligocéne de Dar el Abd (Syrte): Bridelioxylon arnouldi n. sp. II. Sur la présence de Dombeyoxylon oweni (Carr.) Kräusel, 1939, dans le Tertiaire de la Syrte. III. Sur la présence de Sapindoxylon sp. dans le Tertiaire du Nord du Tibesti. C.R. 91e Congr. Natl. Soc. Sav., Rennes, 1966, Sci. 3: 153-172.

Kruse HO. 1954. Some Eocene dicotyledonous woods from Eden Valley, Wyoming. Ohio J. Sci. 54: 243-268.

Li CY, Wang CM, Hsiao JY,Yang CH. 2003. Two fossil dicotyledonous woods from the Kungkuan Tuff (Early Miocene), Northern Taiwan. Coll. and Res. 16: 71-78.

MacFadden BJ, Bloch JI, Evans H, Foster DA, Morgan GS, Rincon AF, Wood A. 2014. Temporal calibration and biochronology of the Centenario Fauna, Early Miocene of Panama. J. Paleontol. 122: 113-135.

MacFadden BJ, Jones DS, Jud NA, Moreno-Bernal JW, Morgan GS, Portell RW, Perez VJ, Wood AR. 2017. Integrated chronology, flora and faunas, and paleoecology of the Alajuela Formation, late Miocene of Panama. Plos One Jan 20, 12 (1): e0170300. 
MacFadden BJ, Jones DS, Morgan DS, Rincon AF. 2015. Gomphothere probiscidean (Gomphotherium) from the late Neogene of Panama. J. Paleontol. 89: 360-365.

Mädel E. 1962. Die fossilen Euphorbiaceen-Hölzer nit besonderer Berücksichtigung neuer Funde aus der Oberkreide Süd-Afrikas. Senckenberg. Lethaea 43: 283-321.

Mehrotra RC, Bera SK, Basumatary SK, Srivastava G. 2011. Study of fossil wood from the middle-late Miocene sediments of Dhemaji and Lakhimpur districts of Assam, India and its palaeoecological and palaeophytogeographical implications. J. Earth Syst. Sci. 120: 681-701.

Mennega A. 1987. Wood anatomy of the Euphorbiaceae, in particular of the subfamily Phyllanthoideae. Bot. J. Linn. Soc. 94: 111-126.

Metcalfe CR, Chalk L. 1950. Anatomy of the dicotyledons. 2 vols. Clarendon Press, Oxford.

Miller RB. 1975. Systematic anatomy of the xylem and comments on the relationship of Flacourtiaceae. J. Arnold Arbor. 56: 20-102.

Nelson CW, Jud NA. In press. Biogeographic implications of Mammea paramerican sp. nov. from the Lower Miocene of Panama and the evolution of Calophyllaceae. Int. J. Plant Sci. 178 (in press; doi: 10.1086/689618).

Normand D. 1955. Atlas des bois de la Côte d'Ivoire. II. Nogent-sur-Marne (Seine), France. 132 pp. Plant rResources of Tropical Africa. Published on the internet (https://www.prota4u. org/).

Prakash U, Brezinova D. 1970. Wood of Bridelia from the Cretaceous of Bohemia. Palaeobotanist 18: 173-176.

Prakash U, Dayal R. 1964. Fossil woods resembling Elaeocarpus and Leea from the Deccan Intertrappean Beds of Mahurzari near Nagpur, India. Curr. Sci. 32: 315-316.

Prakash U, Tripathi U. 1975. Fossil dicotyledonous woods from the Tertiary of eastern India. The Palaeobotanist 22: 51-62.

Prakash-Jangid P, Gupta S. 2016. Systematic wood anatomy of the tribe Phyllantheae (Phyllanthaceae, Euphorbiaceae s.l.) from India: implication in reinstatement of Phyllanthus, Glochidion and allies. Nord. J. Bot. 34: 496-512.

Qi G, Yang J, Xu R. 1997. Three kinds of angiosperm fossil wood excavated from the Late Tertiary strata of Wuhan, China. Liaoning Geology 2: 149-160.

Ramanujan CGK. 1960. Silicified woods from the Tertiary rocks of South India. Palaeontographica 106B: 99-140.

Rodríguez-Reyes O. 2014. Systematics of Miocene angiosperm woods from the Panama Canal and their palaeoenvironmental implications. Unpublished PhD thesis. Royal Holloway, University of London. $414 \mathrm{pp}$.

Rodríguez-Reyes O, Falcon-Lang H, Gasson P, Collinson M, Jaramillo C. 2014. Fossil woods (Malvaceae) from the lower Miocene (early to mid-Burdigalian) part of the Cucaracha Formation of Panama (Central America) and their biogeographic implications. Rev. Palaeobot. Palynol. 209: 11-34.

Stern WL, Eyde RH. 1963. Fossil forests of Ocu, Panama. Science. 140 (3572): 1214.

Stevens P. 2001-onwards. Angiosperm phylogeny website. Published on internet (http://www. mobot.org/mobot/research/APweb).

Stewart RH, Stewart JL, Woodring WP. 1980. Geologic map of the Panama Canal and vicinity, Republic of Panama: USGS Miscellaneous Investigations Series Map I-1232, scale $1: 100,000,1$ sheet.

Watari S. 1956. A large silicified wood of Aleurites from the Miocene of Idilawa prefecture, Honsyu. Bot. Mag. Tokyo 69: 468-473.

Webster GL. 1994. Synopsis of the genera and suprageneric taxa of Euphorbiaceae. Ann. Missouri Bot. Gard. 81: 33-144. 
Wheeler EA. 2011. InsideWood - a web resource for hardwood anatomy. IAWA J. 32: 199211.

Wheeler EA, Manchester S. 2002. Woods of the Eocene Nut Beds Flora, Clarno Formation, Oregon, USA. IAWA J., Suppl. 188 pp.

Whitmore TC. 1998. Potential impact of climatic change on tropical rain forest seedlings and forest regeneration. Climatic Change 39: 429-438.

Williams L. 1936. Woods of northeastern Peru. Field Mus. Nat. Hist. Bot. Ser. 15: 1-587.

Woodring WP. 1957. Geology and paleontology of Canal Zone and adjoining parts of Panama. Geological Survey Professional Paper 306-A, Washington DC, US Government Printing Office. 239 pp.

Wurdack KJ, Davis C. 2009. Malpighiales phylogenetics: gaining ground in one of the most recalcitrant in the angiosperm tree of life. Amer. J. Bot. 96: 1551-1570.

Xi Z, Ruhfel B, Schaefer H, Amorim A, Sugumaran M, Wurdack KJ, Endress P, Matthews M, Stevens P, Matthews S, Davis C. 2012. Phylogenomics and a posteriori data partitioning resolve the Cretaceous angiosperm radiation Malpighiales. PNAS 109 (43): 17519-17524. doi: $10.1073 /$ pnas.1205818109.

Accepted: 10 January 2017 